\title{
Generalisering en differensiëring in die strafregsistematiek
}

Die ordening van die menslike samelewing deur strafregtelike verbods. en gebodsbepalinge het by die meeste volkere reeds in die vroegste stadia van hul ontwikkelingsgang plaasgevind. Die ordening of sistematisering van die strafreg het egter veel later 'n aanvang geneem. In die Nederlande bv. het die tans so bekende onderskeid tussen die algemene en besondere deel van die strafreg eers vroeg in die sestiende eeu gestalte begin verkry, hoewel die nog oormatige aandag wat aan die besondere deel gewy is die algemene deel verdring het na 'n heel beskeie hoekie. Die pendule het egter gestadiglik deurgeswaai en gestimuleer deur talle kodifikasie-poginge het Europese strafreg-juriste, veral gedurende die tweede helfte van die negentiende eeu en die eerste dekades van die twintigste eeu, 'n meer as regmatige plek vir die algemene deel gaan inruim. Hierdie klemverskuiwing sal moontlik in die toekoms nog blyk 'n verskuiwing ten beste te gewees het, omdat kennis van die algemene deel nie noodwendig onkunde of gebrek aan kennis ten opsigte van die besondere deel met sig meebring nie. Inteendeel, die behoorlike samestelling van die algemene deel kon alleen geskied het nadat dit wat algemeen is an alle besondere misdade of sekere groepe van besondere misdade, generaliserend saamgevat is, en vanselfsprekend is kennis van die besondere misdade 'n conditio sine qua non vir genoemde generalisering. Vir die toekomstige sistematisering van die besondere deel vorm die reeds gemelde goed ontwrikkelde algemene deel juis 'n onmisbare fondament; daarom dat ons 
hierbo gewag gemaak het van 'n moontlike verskuiwing ten beste. Blyke dat die verworwe kennis omtrent die algemene deel van die strafreg juis vir die hervorming en herformulering van besondere misdaadomskrywinge geen vrugtelose gepolemiseer was nie, kan ons nou al bespeur in die wysiginge wat sommige Europese strafwetboeke in die jongste verlede ondergaan het. In dié verband kan die invloed van 'n omvangryke en magistrale werk soos die „Vergleichende Darstellung des Deutschen und Ausländischen Strafrechts" op die nuutste Duitse en Switserse strafwetboeke duidelik onderken word.

Om die verband tussen ons opskrif en wat hierbo gesê is, nader te verklaar, kan ons in breë trekke die ontwikkelingsgang van die strafreg as volg saamvat: (1) oormatige differensiëring sonder ratio vir al die onnodige verskille-d.i. by die reekse primitiewe gebods- en verbodsbepalinge; (2) generalisering by die samevatting van dit wat gemeen is aan alle of sekere besondere misdade-samestelling van die algemene deel van die strafreg, en ( 3 )meer oordeelkundige differensiëring deurdat die grense wat die reeds gegeneraliseerde deel van die strafreg diaarstel, in ag geneem word. Van hierdie drie fases sal slegs laasgenoemde tydperk (wat maar so pas begin het) ons aandag verg.

Oor generalisering en differensiëring by die sistematisering van die algemene deel van die strafreg sal ons slegs 'n enkele woord laat val en wel in verband met die kousaliteitsvraagstuk.

$\mathrm{Na}$ die mening van skrywer hiervan bestaan daar geen juridiese kousaliteitsleer wat nie of te veel of te weinig sê nie. Die generalisering by die definiëring van die oorsaaklikheidsbegrip is dus te wyd of te eng. Te eng bv. is die leer van adekwate veroorsaking van von Kries wat 'n wederregtelike behandeling as oorsaaklik beskou wanneer hierdie wederregtelike handeling volgens algemene ervaring die ingetrede verbode gevolg laat intree-te eng is dit omdat ' $n$ juridies relevante oorsiak wel deeglik buite die algemene ervaring kan val. Die objektief „nachträgliche Prognose" wat Rümelin voorstaan, is 'n verbetering op die leer van von Kries maar bevredig nog geensins--sy konkretisering van wederregtelike gedrag en ingetrede gevolg "nach Massgabe unserer Erkentnissfähigkeit" skiet nog steeds te kort om alle juridies relevante oorsake te dek. In teëstelling hiermee dek die conditio sine qua nonleer wel alle juridies relevante oorsake, maar 'n bevredigende antwoord op die vraag hoe die relevante van die irrelevante onderskeie moet word, word deur hierdie leer nie gegee nie, altans teoreties nie; in die 
praktyk val egter heelwat van die teoretiese besware weg, omdat die praktyk nie gemoeid is met al die conditiones wat onontbeerlik is vir die intrede van die gewraakte gevolg nie. Trouens die wederregtelikheids-element, asook die beheerbaarheid of vermybaarheid van die kousale verloop deur die vermeende d.ader, gee grotendeels al 'n leidraad vir die differensiëring tussen die relevante en irrelevante oorsake. Generaliserend kan hierdie differensiëringsmiddele egter nie saamgevat word nie. Om dit korter te stel, die juridiese kousaliteitsbegrip, sover ons daarmee in die strafreg te doen het, kan nie sodanig gegeneraliseer word dat dit sonder kasuïstiese tendense van andersoortige kousaliteitsbegrippe gedifferensieer kan word nie.

Moontlik sal 'n beter resultaat verkry word indien die kousaliteitsvraagstuk as sulks minder aandag geniet en meer tyd bestee word om die vraag na die toerekenbaarheid van die kousale verloop aan 'n aader, aan 'n deeglike ondersoek te onderwerp. Om egter nie in dieselfde foute te verval as die leer van adekwate veroorsaking nie, sal die koppeling van bogemelde toerekenbaarheid aan die subjektiewe insig of algemene ervaring van of die dader óf die beoordelaar van die materiële misdaad sorgvuldig vermy moet word. Veroorsaking van 'n bepaalde gevolg is iets objektiefs wat 'n dader toegereken word en daarom het sy (die dader se) insig omtrent die kousale verloop met kousaliteit niks te make nie. Blyk dit dat die dader die gevolge van sy optrede nie kon realiseer het nie, mag die skuldelement moontlik afwesig geag word, maar hierdie blyke het geen invloed op die vraag na die aan- of afwesigheid van die oorsaaklikheidsverband nie. Wanneer von Hippel dus beweer: „(Es ist) ein logisch unsauberes und deshalb abzulehnendes Verfahren objektiv unerhebliche Bedingungsverhaltnisse für erheblich zu erklären, um sie dann erst über den Umweg der Schuldlehre weder unerheblich zu machen"') is dit ons duidelik dat hy nie behoorlik onderskeie het tussen die objektiewe wat by die kousale verloop en die subjektiewe wat deur die beantwoording van die skuldvraag aan die dader toegereken word nie. Op die probleme wat hierdie gebrek aan onderskeiding meebring, kan ons nie nou ingaan nie; ons volstaan met die vermyding daarvan vir die toekoms te bepleit.

In vele opsigte is die sistematisering van die besondere deel van die strafreg makliker as die van die algemene deel; die besondere mis-

1) Zeitschrift für die gesante Strafrechtwissenschaft, Bd. XLVII, p. 27. 
dade is $\mathrm{nl}$. reeds min of meer gegroepeer volgens die regsbelange wat deur elke groep aangetas word. So word bv. gepraat van die misdade teen die lewe, teen die staatsgesag, teen die vermoë, en so meer. 'n Indeling van misdade volgens die aangetaste regsbelang is egter nie konsekwent deur te voer nie, daar by sekere misdade geen regsbelang aangewys kan word nie en by andere die „regsbelang” heeltemal te abstrak is om nog as 'n regsbelang beskou te word. Geen wonder dat daar gekla word dat ,de systematiek van het bijzondere deel van het strafrecht ..... is fragmentarisch",2). Van Bemmelen bv. ag dit wenslik dat daar by die indeling van die besondere misdade ook rekening gehou sal word met die „onderliggende zedelijke norm"3). Hiermee sal die kriteria vir die differensiëring van groepe misdade egter nog nie uitgeput wees nie. Om dit kort te stel, daar bestaan nie 'n kriterium waarvolgens groepe misdade van mekaar onderskeie kan word nie; wel kan gepraat word van verskillende kriteria vir hierdie doel. Die sistematisering van die misdade in afsonderlike groepe kan ons tans buite bespreking laat, om aandag te skenk aan die sistematisering van die misdade binne bepaalde groepe.

Tot onlangs het die Europese strafwetboeke oorwegend die neiging openbaar om binne bepaalde groepe van misdade te veel te differensieer en te weinig aandag te skenk aan die moontlikheid van integrasie van hierdie misdaad deur samevattende misdaadsomskrywinge; m.3.w. deur generalisering toe as pas. I.v.m. die oormatige differensiëring het von Liszt reeds bykans vyftig jaar gelede gesê: „Und je grőser die Kasuistik des Gesetzes, desto grösser ist die Gefahr, dass dem einzelnen Fall Gewalt angetan und der eigentliche Wille des Gesetzes in sein Gegenteil verkehrt werde. Knappe Kürze ist vielmehr das Ziel, das jeder moderne Gesetzgeber sich stellt und das daher der Gesetzgeber der Zukunft erst recht sich stellen muss".) Vir hierdie onnodige differensiëring is tradisie-gebondenheid grotendeels verantwoordelik, hoewel die gekompliseerder wording van ons moderne samelewing hierby ook geen geringe rol gespeel het nie.

Die huidige Nederlandse strafwetboek onderskeie bv. nog steeds tussen moord, doodslag, kindermoord, kinderdoodslag, hulpverlening by selfmoord, doodslag op versoek van die slagoffer en gekwalifiseerde

i) Van Bemmelen-van Hattum: Hand- en Leerboek van het Nederlandsche Strafrecht II, p.8.

3) A.w., p.55. 
doodslag. By diefstal word weer 'n verskil gemaak tussen gewone diefstal en gekwalifiseerde diefstal, wat dan bestaan uit diefstal van vee, diefstal by geleentheid van brand, ontploffing ens. Oor heelwat van hierdie differensiëringe hoef nie eers geredeneer te word nie hulle kan eenvoudig weggedoen word. Andere, soos die tussen moord en doodslag is tot dusver gehandhaaf bloot vanweë die gewoonte om hier 'n verskil te sien, terwyl hierdie twee misdade heel maklik saamgevoeg kan word sonder dat enigeen van die twee van sy geldingsgebied hoef prys te gee. Die generalisering wat reeds in die algemene deel van die strafreg, met name in verband met die skuldelement gedoen is, kan hier genoegsame hulp bied. Die tradisie om moord as 'n ern. stiger vorm van doodslag te beskou, nl. as doodslag wat heimelik en fyn berekend gepleeg is, merk ons selfs in die heel nuutste poginge om moord te omskrywe, en wel in die Switserse art. 112, wat as volg lui: „si le deliquant a tué dans des circonstances ou avec une prémeditation denotant qu'il est particulièrement pervers ou dangéreux, il sera de la réclusion à vie". Hier is wel gedifferensieer tussen moord en doodslag, maar die omskrywing wat van moord gegee word, word in te algemene terme gestel. Die omstandighede waaruit die perversiteit of gevaarlikheid van die dader moet blyk, is heeltemal te vaag om enige houvas aan 'n strafregter te bied. Bowendien het hierdie besondere artikel nog tot gevolg dat by die misdade teen die lewe nie alleen versagtende omstandighede in ag geneem kan word nie, maar ook verswarende omstandighede. Onses insiens moet 'n misdaadsomskrywing so omvattend as moontlik wees-dit het die voordeel dat dan slegs versagtende en geen verswarende omstandighede in ag geneem hoef te word nie. Die generaliseerbaarheid van die elemente van die misdaad (resp. misdade) moet ten volle benut word. Deur alle wederregtelike lewensberowing te differensieer volgens die twee bekende skuldvorme dolus en culpa en geen verdere differensiëringe te mak nie, word die sistematiese indeling van die misdade teen die lewe heelwat eenvoudiger en tog word hiermee geen nuwe probleme geskep nie. Dit wat buitendien nie generaliseerbaar is nie-ons doel hier op die verskillende omstandighede wat ter versagting van die straf aangevoer kan word-word dan ook heel tereg aan die diskresie van die regter oorgelaat. Om die regterlike willekeur te wil voorkom deur alle versagtende en verswarende omstandighede te laat dien as kriteria wararvolgens verskillende grade van lewensberowing omskryf word, skep meer probleme as wat dit oplos. 
Immers ' $n$ behoorlike sistematiek veronderstel tog dat dit wat generaliseerbaar is, sonder om in die belaglike te verval, wel gegeneraliseer is, en dat dit wat nie deur die generalisering gedek kan word nie, daarvan gedifferensieer word, maar sonder om in die kasuistieke te verval.

Dieselfde verskynsel tref ons aan ten aansien van die misdade wat gevaar skep vir die lewe. Die meeste Europese strafwetboeke differensieer hier nog steeds na gelang van die erns van die ingetrede gevolg. So word mishandeling in die Nederlandse wetboek bv. onderverdeel in gewone (opsetlike) mishandeling, mishandeling wat swaar liggaamlike letsel ten gevolge het en mishandeling wat die dood ten gevolge het. Ook hierdie differensiëring is totaal onnodig en is selfs van primitiewe „Erfolgshaftung" nie vry te pleit nie. Deur die maksimumstraf wat gestel word op gewone mishandeling heelwat te verhoog, kan weggedoen word met die onderskeid tussen gewone mishandeling en mishandeling wat ernstige liggaamlike letsel ten gevolge het. Deur aanwending van concursus idealis en 'n verhoging van die straf op homicidium culposum sal die noodsaak vir die afsonderlike bestraffing van mishandeling ,de dood ten gevolge hebbende" wegval. Hiermee sal die wetboek aan eenvoud wen en terselfdertyd die beginsel van "Schuldhaftung" beter tot sy reg laat kom. Die bogemelde onnodige differensiëring tussen mishandeling en mishandeling wat die dood tot gevolg het, is des te meer verstommend waar die Nederlandse strafwetboek self die weg wat behoort gevolg te word, aandui in artikel 55 onder die titel "Samenloop van strafbare feiten"--ons doel hier op sameloop van mishandeling en homicidium culposum.

Soos op vele ander gebiede blyk dit ook vir die strafreg waar te wees dat oormatige differensiëring nie altyd die uitkoms van goeie onderskeidingsvermoë is nie. Waar die onderskeidingsvermoë nie gebrekkig is nie, sal dit wat by mekaar hoort by mekaar geplaas word; daar sal dus korrek gegeneraliseer word sonder om te differensieer dit wat nie hoef gedifferensieer te word nie. Deur eenvoud te betrag, sal elke wetgewer sowel die akademikus as die praktikus 'n diens bewys.

S. POSTMA.

P.U. vir C.H.O. 